\title{
Translation Equivalence of English Passive Constructions in Literary Discourse in Vietnamese
}

\author{
Pham Thi Thuy ${ }^{1}$ \\ ${ }^{1}$ International School, Vietnam National University, Hanoi, Vietnam \\ Correspondence: Pham Thi Thuy, International School, Vietnam National University, Hanoi, (VNU-IS). Tel: \\ 84-9-1268-1269. E-mail: thuypt@isvnu.vn
}

Received: September 12, 2021

Accepted: September 29, $2021 \quad$ Online Published: November 29, 2021

doi:10.5539/ass.v17n12p12

URL: https://doi.org/10.5539/ass.v17n12p12

\begin{abstract}
Translation of English passive constructions into Vietnamese has been of interest to scholars and researchers worldwide. However, not much research has been done into translation equivalence of the English passives in Vietnamese. This paper aims to explore into the translation equivalence of English passive constructions in Vietnamese in literary discourse. To reach this aim, data were collected from classic works of American and English literature and their translations in Vietnamese. The data were further analysed and classified, applying Widdowson's (1979) trichotomy of translation equivalence. The research findings show five strategies for translating the English passives into Vietnamese with this order of frequency: activization, passivization, ergativization, adjectivalization, and copularization, and the translation equivalence includes both structural and semantic. The paper also attempts to explain the reasons behind the preference of activization strategy.
\end{abstract}

Keywords: English-Vietnamese translation equivalence, passive constructions, literary discourse, structural and semantic equivalence

\section{Introduction}

Translation of English passive constructions into other languages has been of interest to scholars and researchers worldwide. There have been a number of studies on translation of English passives into other languages, such as German, Russian, Chinese and Japanese (Baker, 1992), Arabic (Farghal \& Al-Shorafat, 1996; Nahar Al-Ali \& Alliheibi, 2015); Farsi (Abbasi \& Arjenan, 2014), or Vietnamese (Luu, 2010; Hoang, 2015).

Baker (1992, p. 107) points out differences in frequency of using passive voice in English, German, Russian, as well as in the use of passives in Asian languages, namely Japanese, Chinese, Vietnamese and Thai. In these Asian languages, the passive has the connotation of unpleasantness 'even the event depicted is not normally seen as unpleasant'. She also states that the trend to translate English passives literally into these languages, i.e. with correspondent passive constructions, 'is often criticized by linguists and by those involved in training translators' (ibid. p. 102). The study by Farghal \& Al-Shorafat (1996) shows that the strategies that translators use to translate the English passives into Arabic include nominalization, adjectivalization, passivization, activization and pseudo-activization. In another study on the translation of English passives into Arabic, Nahar Al-Ali \& Alliheibi (2015) demonstrate that the Arab student- translators transform English passives into verbal nouns, pseudo-passive verbs or active sentence structures, or into vowel melody passives, or even omit the passive structures. In their study on the translation of English passives and unaccusatives into Farsi, Abbasi \& Arjenan (2014) have come to the conclusion that using actives in translation of passives and unaccusatives is appropriate for Farsi grammar, and Farsi readers.

The study by Luu (2010) proposes some strategies for translating English passive structures into Vietnamese in a number of medical texts, such as using impersonal active structures, active structures, passive structures, and nominalization. Nevertheless, Luu's study limits itself to scientific discourse, leaving translation of English passive constructions in other discourses, such as literary, open for discussion. Hoang (2015) explores the translation of English passive sentences in different discourses, namely scientific, literary, and administrative, and discovers three strategies for translating English passives into Vietnamese: passive sentences, active sentences, and middle sentences. However, Luu (2010) and Hoang (2015) do not yet demonstrate what types of translation equivalence exist between the English passives and the translated sentences in Vietnamese. This is also the rationale for our study. 


\section{Theoretical Background of the Study}

\subsection{The Concept of Translation Equivalence and Types of Translation Equivalence}

\subsubsection{The Concept of Translation Equivalence}

The discussion on the nature of translation equivalence has been going on for decades. 'Equivalence is a central concept in translation theory, but it is also a controversial one' (Kenny, 2009, p. 96). In general, there are three main approaches to the concept of translation equivalence.

Scholars of the first approach (Catford, 1965; Nida \& Taber, 1969/1982; Koller, 1989) admit that there is translation equivalence, which is based on the comparison between the source text and the target text. Translation equivalence, an empirical phenomenon, is 'discovered by comparing source-language (SL) and target-language (TL) texts' (Catford, 1965, p. 27). Nida \& Taber (1969/1982, p. 12) define translation as the reproduction in the target language 'the closest natural equivalent of the source-language message' with regard to the meaning and the style. In Koller's views (1989, p. 100), equivalence exists 'between a given source text and a given target text if the target text fulfils certain requirements' with reference to the aspects, such as content, form style, function, and so on. In contrast to the first approach, the scholars of the second approach reject the notion of equivalence, stating that 'equivalence is unsuitable as a basic concept in translation theory' because it is 'imprecise and ill-defined', (Snell-Hornby, 1988/1995, p. 22). The theorists of the third approach take a neutral perspective. They acknowledge that there is translation equivalence, but regard it as a relative concept (Baker, 1992, p. 6).

This study adopts the first approach to translation equivalence, according to which there exists translation equivalence, and it should be based on the SL text and TL text relations.

\subsubsection{Types of Translation Equivalence}

A number of types of translation equivalence have been discussed by scholars, such as Nida (1964/2000), Koller (1989), Baker (1992), Widdowson (1979), among others.

Nida (1964/2000) proposes two types of equivalence: formal equivalence and dynamic equivalence. A formal equivalence translation is basically source-oriented; that is, it is designed to reveal as much as possible of the form and content of the original message. A dynamic equivalence translation is the closest natural equivalent to the source- language message, (Nida, ibid, pp. 129-134). Koller (1989) distinguishes five different meaning-based types of equivalence, namely denotative equivalence, connotative equivalence, text-normative equivalence, pragmatic equivalence, and formal equivalence (or artistic-aesthetic equivalence). Baker's (1992) translation equivalence is considered form-based, and the equivalence can be at word level, or above word level, such as collocations, idioms and fixed expressions. The four main types of meanings in words should be taken into consideration while looking at equivalence at word level: propositional meaning, expressive meaning, presupposed meaning, and evoked meaning (Cruise, as cited in Baker, 1992, p. 13).

Widdowson (1979) distinguishes three types of equivalence at the sentence level, namely structural, semantic and pragmatic. Firstly, structural equivalence makes direct reference to surface forms. For example, the English sentencesin (1) and (2) below are viewed as structurally equivalent to the French sentences (3) and (4), respectively, Widdowson (ibid, p. 61):

(1) The postman opened the door.

(2) The door was opened by the postman.

(3) Le facteur ouvrit la porte.

(4) La porte fut ouverte par le facteur.

Secondly, semantic equivalence refers to the propositional content of sentences independently of their surface forms, i.e. sentences expressing the same propositional content may be considered semantically equivalent to (1) - (4) above, although they may have different surface forms as described in (5) - (8) below (ibid, p. 62):

(5) It was the postman who opened the door.

(6) It was the door that was opened by the postman.

(7) Ce fut le facteur qui ouvrit la porte.

(8) Ce fut la porte qui fut ouverte par le facteur.

Thirdly, pragmatic equivalence refers to the illocutionary effect of utterances, thus, cannot be established in relation to isolated sentences but only by making references to what utterances count as in context. However, while contextual variation still needs to be considered, sentences (9) and (10) may be regarded pragmatically 
equivalent to (1) and (2) above (ibid, p. 62):

(9) Le facteur a ouvert la porte.

(10) La porte a été ouverte par le facteur.

For the purpose of this paper, we will adopt Widdowson's (1979) trichotomy of equivalence: structural, semantic and pragmatic equivalence, because of its comprehensiveness and validity in the context of translation, and its relevance to the structural machinery which is overlooked in other theories of equivalence. The structural and semantic equivalents are relevant to theoretical analyses, and Chomsky's deep structure and surface forms are taken into account. More specifically, in this study we will use Widdowson's classification of structural and semantic equivalence, as the data are isolated sentences.

\subsection{English Passives and Their Vietnamese Counterparts}

\subsubsection{English Passives}

Quirk, Greenbaum, Leech \& Svartvik (1985) distinguish three kinds of passives, namely central passive, semipassives, and pseudo-passives. Central passive or 'true passive' sentences have a direct active-passive relation, that can have expressed or no expressed agent (e.g. 'The violin was made by my father'), while semi-passives or mixed-passives are cases when the verbs have both verbal and adjectival properties (e.g. 'We are encouraged to go on with the project'). And lastly, pseudo-passives are cases when sentences have neither an active transform nor a possibility of agent addition (e.g. 'The building is already demolished') ${ }^{1}$. Sentences of this type are called 'pseudo-passives', sinceit is chiefly only their superficial form of verb + -ed participle that recommends them for consideration as passives (ibid, p. 167). The active - passive correspondence in English is provided as follows.

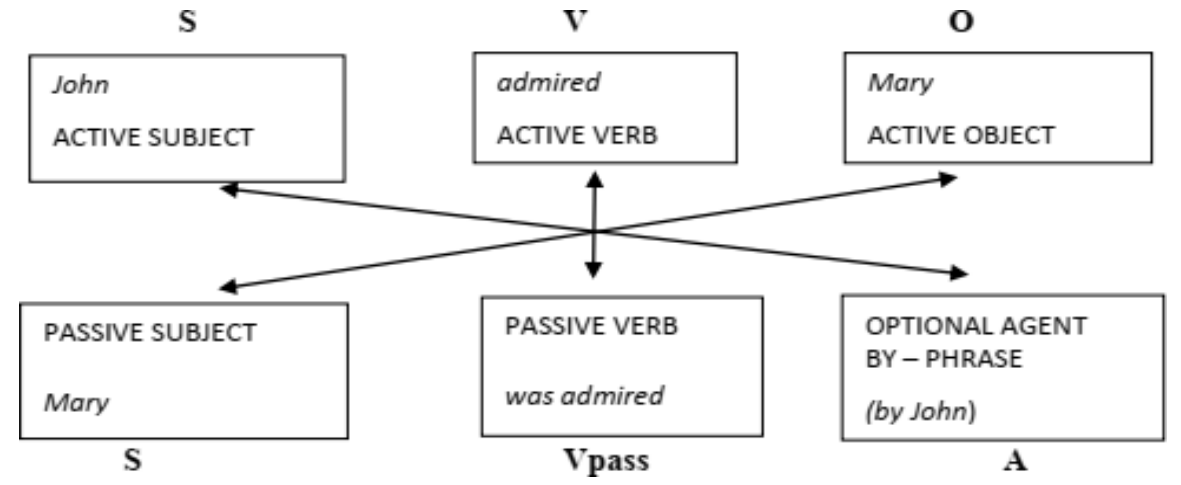

Figure 1. The active - passive correspondence in English (Quirk et al. 1985, p. 160)

Besides active voice and passive voice, in English also exists middle voice, which 'describes an action which is performed by the subject for his/her own benefit or in which the subject affects itself' (Bussmann, 1996, p. 748). The middle voice is formed with middle verbs. Middle verbs include (i) verbs which can neither form a passive nor be combined with modal adverbs, such as 'resemble', 'cost', 'fit', 'weigh', and (ii) verbs with passive-like meaning, such as 'open' (Bussmann, ibid, p. 747). Keenan \& Dryer (2007, p. 353) also differentiate between middle sentences and passive sentences in English: the passives have additional entailment about agents that caused the activity, while the middle sentences don't have it, e.g. 'The ship was sunk (by the enemy)' vs. 'The ship sank'. In this study, we refer to middle verbs, type (ii), in Bussmann above as ergative verbs in the translation analysis.

\subsubsection{Vietnamese Passives}

The issues of passive voice and passive sentences in Vietnamese have been discussed in numerous studies over the last decades (see Thompson, 1987; Clark, 1974; Nguyen, 1977; Nguyen, 1986; Dinh, 1986; Alves, 1998; Nguyen, 2000; Cao, 2001; Nguyen \& Bui, 2004; Diep, 2006; Keenan \& Dryer, 2007; Simpson \& Ho, 2008; Nguyen, 2009). The question of whether in Vietnamese, a highly analytic language, exist passive voice and passive sentences has always been in the centre of discussion. In general, there are two opposing approaches to passive sentences in Vietnamese: absence and presence of passive sentences in Vietnamese (for more detail, see Diep, 2006, p. 150; Nguyen, 2009).

The present study adopts the second approach, according to which in Vietnamese language exist passive sentences with specific criteria differentiating passive sentences in Vietnamese from active ones (see Nguyen, 2009, pp. 112-113). 
The transformation of Vietnamese active sentences into corresponding passive sentences can be described in the following table:

\begin{tabular}{|c|c|c|c|c|c|}
\hline No. & NP1 & V & NP2 & & (active sentence) \\
\hline 1 & NP2 & được/bị & $\mathrm{V}$ & & (non-agentive passive sentence) \\
\hline 2 & NP2 & được/bị & NP1 & $\mathrm{V}$ & (passive sentence with agentive oblique NP) \\
\hline 3 & NP2 & được V & bởi & NP1 & (passive sentence with agentive PP) \\
\hline
\end{tabular}

(NP1 - Agentive NP, NP2 - Patient NP, V- Predicative Verb, ‘được/bị’’ passive markers)

(H.C. Nguyen, 2009, p. 113)

The following examples are taken from H.C Nguyen (2009, pp. 113-114):

(1a) Nó được khen. [He was praised.] （1b) Tôi bị mắng. [I was scolded.]

(2a) Nó được thầy khen. [He-was-teacher-praised.] (2b) Tôi bị mẹ mắng. [I-was-mother-scolded]

(3) Ngôi nhà này được xây dựng bởi những tay thợ lành nghề. [This house was built by skillful builders.]

Besides active and passive sentences, scholars also state that in Vietnamese exist middle sentences. Differences between Vietnamese pseudo-passive sentences, true passive sentences and middle sentences are discussed in Diep (2006), Nguyen (2009), and others. Pseudo-passive sentences in Vietnamese are passive in terms of grammatical forms, but active in terms of semantics (Nguyen, 2009, p. 116). These sentences have the subject NP1 indicating the actor of the experience with the structure of the predicate. The predicative could be an intransitive verb or a transitive verb. Pseudo-passives differ from the typical passive sentences in that they do not accept an agentive NP1 before the verb (e.g. 'Tôi bị ngã' ('I suffer fall' = 'I fell') (Nguyen, 2009, p. 116). Meanwhile, middle sentences are between passive and active sentences, which are also termed de-transitive sentences, (e.g. 'Cửa mở rồi'('Door open already' = 'The door opened') (Nguyen 2009, p. 117). The verbs often seen in this type of sentences include 'mở' ('open'), 'xây' ('build'), 'dừng' ('stop'), 'bán' ('sell'), etc. (Diep, 2006, p. 152; Nguyen 2009, pp. 117-118). Again, we use the notion of ergative verbs for this type of verbs in this study.

\subsubsection{Summary}

To summarize, in this study we adopt the views that there exists translation equivalence between the SL text and the TL text. The translation equivalence trichotomy at sentence level by Widdowson (1979), especially the two types of equivalence, structural and semantic, has been adopted as the analytical framework in this study. We also take the approach that Vietnamese language has passive sentences, and employ Quirk et al's (1985) active-passive correspondence in English and H.C. Nguyen's (2009) active-passive correspondence in Vietnamese.

\section{The Present Study}

\subsection{Data of the Study}

The present study focuses on the translation of English passive sentences into Vietnamese in literary discourse. The data consist of 150 English passive sentences collected from four short stories and a novella by Jack London, namely 'ADay's Lodging', 'Love of Life', 'The White Silence', 'The Son of the Wolf', and 'The Call of the Wild', and from the novel Pride and Prejudice by Jane Austen, and their translations in Vietnamese (see the sources for the data). These stories, novella and novel have been chosen for this study because they are classic works of American and English literature. Jack London's works have been taught in Vietnamese schools, and Pride and Prejudice has recently been made into film, which has been also shown on TV in Vietnam.

\subsection{Research Questions and Research Methods}

As indicated in the Introduction, the few studies on the translation of English passives into Vietnamese have only pointed out the strategies for translating English passives into Vietnamese, without indicating what kind of translationequivalence exists between the English passives and their translated sentences. This study attempts to answer the following two research questions:

(1) Is the translation equivalence between English passive sentences and their Vietnamese counterparts structural, or semantic?

(2) What are some possible factors that may influence the choice of certain translation strategies?

The research methods employed in this study is contrast analysis. First, English passive sentences and their translations 
have been collected. The criterion for data collection: English passive sentences must be independent clauses, or mainclauses, not subordinate ones. An independent clause is a group of words that includes a subject and a verb, and can form a sentence (Oxford Learners' Dictionary). After that, the translated sentences have been analysed, and further classified based on Widdowson's (1979) classification of translation equivalence (structural and semantic) at sentence level.

\subsection{Data Analysis and Discussion}

As stated earlier in this paper, the data from the literary texts consist of 150 English passive sentences and their translations in Vietnamese. Some sentences in the data comprise two or three independent clauses, making the total number of clauses in the data is 157 , thus, in the following section, we will analyse the translations based on the clauses. Also, the terms 'sentence' and 'clause', i.e. 'independent clause', are used interchangeably in this paper.

The results of the study show that there are five strategies for translating the English passives into Vietnamese. These are:

- passives into passives,

- passives into actives (transitive verbs and intransitive verbs),

- passives into ergative verbs,

- passives into adjectives or adjectivals, and

- passives into copular verbs.

Table 1. Strategies for translating English passives into Vietnamese

\begin{tabular}{ccccccc}
\hline \multirow{2}{*}{$\begin{array}{c}\text { Translation } \\
\text { strategies }\end{array}$} & Passiveclauses & Active clauses & Clauses with & $\begin{array}{c}\text { Clauses with } \\
\text { adjective/ adjectival } \\
\text { phrase }\end{array}$ & $\begin{array}{c}\text { Clauses with } \\
\text { copular verb }\end{array}$ \\
\cline { 3 - 4 } $\begin{array}{c}\text { Number of clauses } \\
\text { (/157) }\end{array}$ & 61 & 54 & 22 & 12 & 5 & 3 \\
$\%$ & $38.85 \%$ & $34.39 \%$ & $14.01 \%$ & $7.64 \%$ & $3.18 \%$ & $1.91 \%$ \\
\hline
\end{tabular}

In the next part, detailed analysis of each translation strategy will be presented.

\subsubsection{English Passives Translated into Vietnamese Passives}

As can be seen in Table 1 above, 61 out of 157, i.e. 38.85\%, English passive clauses have been translated into Vietnamese passive ones. Among these 61 clauses, 58 Vietnamese translated clauses have the structure corresponding to that of English passives, while the rest three clauses have a slightly different structures.

Examples of Vietnamese translated clauses with corresponding structures with English passives:

(1) His desperate courage was evicted by a great surge of fear.

$\begin{array}{lllllllll}\text { Sự can đảm } & \text { của } & \text { gã } & \text { bị } & \text { một } & \text { nỗi sợ } & \text { dâng trào } & \text { mãnh liệt } & \text { đánh bật ra. } \\ \text { (courage } & \text { of } & \text { he } & \text { be } & \text { one } & \text { fear } & \text { surge } & \text { greatly } & \text { evict) }{ }^{2}\end{array}$

The above translated sentence follows the passive structure: NP2 - được/bị- NP1-V (H.C. Nguyen, 2009, p. 113).

(2) It was then disclosed in the following manner.

Câu chuyện bấy giờ được tiết lộ theo cách thức như thế này.

(story then be disclose according to manner like following)

This Vietnamese example has the structure: NP2 - được/bị-V (H.C. Nguyen, 2009, p. 113).

Three Vietnamese translated clauses with non-corresponding structures with English passives

Table 2. Translation of English passives into Vietnamese passives

\begin{tabular}{ccc}
\hline $\begin{array}{c}\text { Number of English } \\
\text { passive clauses }\end{array}$ & \multicolumn{2}{c}{$\begin{array}{c}\text { Number of translated Vietnamese passives } \\
61(38.85 \%)\end{array}$} \\
\hline \multirow{2}{*}{157} & $\mathrm{~S}-\mathrm{V}-\mathrm{O}$ corresponding to Englishpassives & $\mathrm{S}-\mathrm{V}-\mathrm{O}$ non-corresponding to Englishpassives \\
& $58(36.94 \%)$ & $03(1.91 \%)$ \\
\hline
\end{tabular}


(3) Three more huskies were added to the team inside an hour,... $\begin{array}{lllllllllll}\text { Trong vòng } & \text { một } & \text { tiếng, đàn } & \text { chó } & \text { được } & \text { tăng cường thêm } & \text { ba } & \text { con chó } & \text { Ét-ki-mô nũa, ... } \\ \text { (within } & \text { one } & \text { hour, team } & \operatorname{dog} & \text { be } & \text { reinforce } & \text { three } & \operatorname{dog} & \text { Eskimo } & \text { more) }\end{array}$ (= Within one hour, the dog team was reinforced with three more huskies)

In the above translation, the object 'the team' of the verb 'reinforce' becomes the subject in the translated passive sentence. The Vietnamese passive structure would be completely corresponding with the English passive if it were translated as 'Ba con chó Ét-ki-mô được tăng cường thêm cho đàn'(three-dog- Eskimo-be-add-for-team).

(4) The life of only one member was demanded...

$\begin{array}{lllllllllll}\text {... mà } & \text { chỉ có } & \text { một } & \text { thành viên } & \text { của } & \text { đàn } & \text { là } & \text { bị } & \text { đòi } & \text { nộp } & \text { mạng. } \\ \text { (... that } & \text { only have } & \text { one } & \text { member } & \text { of } & \text { team } & \text { be } & \text { bị } & \text { demand } & \text { submit } & \text { life })\end{array}$

(= that only one member of the team was to be demanded to submit his life)

In the above translated sentence, part of the passive subject 'one member' has been rendered as the subject of the Vietnamese passive, while the word 'life' has been made into the object of the verbs 'demand to submit', which changes the structure of the English passive.

It should be noted that all the three translated sentences were taken from the same translation 'Tieng goi noi hoang da'('The Call of the Wild') by one translator. Two among these sentences are with the verb 'add' ('bổ sung'), and the third one - 'demand'. Also, these translated sentences sound natural in Vietnamese.

In short, from the analysis in this section, 3.3.1, it can be said that 58 Vietnamese passive clauses are complete structuralequivalence of the English passives, while the rest 3 Vietnamese passive clauses may be classified as incomplete structural equivalence of the English passives.

\subsubsection{English Passives Translated into Vietnamese Actives}

According to H.C. Nguyen \& Bui's (2004), there are two types of Vietnamese active sentences: actives with transitive verbs, and actives with intransitive verbs. In the following section, we will analyse the translated Vietnamese sentencesin H.C. Nguyen \& Bui’s views (2004).

Table 3. Translation of English passives into Vietnamese actives

\begin{tabular}{ccc}
\hline Number of English passiveclauses & \multicolumn{2}{c}{ Number of translated Vietnamese active clauses } \\
$76(48.4 \%)$
\end{tabular}

English passives translated into Vietnamese actives (transitive verbs)

Among the 54 translated Vietnamese active clauses, we have seen two ways the clauses are structured: first, the translated clauses have a corresponding S-V-O structure with that of the English passive, which include the translations of English passives with empty 'it'; and second, the translated clauses have a non-corresponding structure.

Table 4. Translation of English passives into Vietnamese actives (transitive verbs)

\begin{tabular}{|c|c|c|}
\hline \multirow{3}{*}{$\begin{array}{l}\text { Number of Englishpassive } \\
\text { clauses }\end{array}$} & \multirow{2}{*}{\multicolumn{2}{|c|}{$\begin{array}{l}\text { Number of translated Vietnamese active clauses (transitive verbs) } \\
\qquad 54(34.4 \%)\end{array}$}} \\
\hline & & \\
\hline & Clauses with correspondingstructures & Clauses with non-correspondingstructures \\
\hline 157 & $34(21.7 \%)$ & $20(12.7 \%)$ \\
\hline
\end{tabular}

In what follows, we will provide examples of these translations.

Translated Vietnamese active clauses with passive - active corresponding structures

(5) They were crazed by the smell of the food.

$\begin{array}{lllll}\text { Mùi } & \text { thức ăn } & \text { làm } & \text { chúng } & \text { điên cuồng lên. } \\ \text { smell } & \text { food } & \text { make } & \text { they/them } & \text { craze/ crazed }\end{array}$

(= The smell of the food crazed them.) 
In example No.5 above, the agentive object in the English original passive sentence has been translated into the subject in the Vietnamese active one, i.e. it follows Quirk et al's (1985, p. 160) active-passive correspondence.

(6) So the sled lashings were cut, and the sufferer, rolled in furs, laid on a couch of boughs.

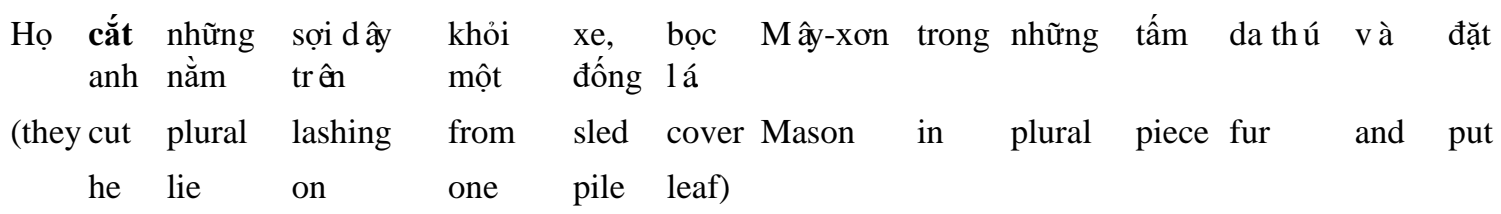

In example No.6 the hidden agent in the English passive sentence, i.e 'they', becomes the subject in the translatedVietnamese active sentence.

Translation of English passives with 'it' as the subject into Vietnamese actives (transitive verbs)

In the data of this study, all the four English passive sentences with the subject 'it' have been translated into

Vietnamese actives with transitive verbs.

Table 5. Translation of the subject 'it' into Vietnamese

\begin{tabular}{ccc}
\hline No. & Subj. in the English passives & Subj. in the translated Vietnamese actives \\
\hline 1. & 'it' & mọi người ('everyone') \\
2. & người ta ('people') \\
3. & mọi người ('everyone') \\
4. & Bà ('lady', 'Madam', 'Mrs', 'Miss') \\
\hline
\end{tabular}

(7) It was noticed that the man was getting fat.

$\begin{array}{llll}\begin{array}{l}\text { Người ta nhận thấy gã } \\ \text { People notice béo }\end{array} & \text { he rat } & \text { more } \\ \text { People noticed he got fatter) } & & & \end{array}$

'It' when used in the passive voice makes the sentence seem less personal and more objective ${ }^{3}$. The literal passive translation of example No. 7 in Vietnamese may be: 'Điều được nhận thấy là gã béo ra'.

However, if we compare the literally translated passive version and the active version, a native Vietnamese will choose the active one, as it sounds more natural in Vietnamese. The claims that passive voice is not preferred in Vietnamese (see K. T. Nguyen, 1975, p. 211; Tran, 1998, p. 165) appear to be correct in this case.

As can be seen in Table 5, all the four English passive sentences with the subject 'it' have been translated into the Vietnamese active counterparts, in which the passive hidden agents, such as 'people', 'every one' or 'Madam', become the subjects in the Vietnamese actives. Thus, the structures of Vietnamese translated sentences can be considered corresponding with those of the English ones.

Translated active Vietnamese clauses with passive - active non-corresponding structures (transitive verbs)

In this study, we have found 20 English passive clauses translated into Vietnamese active (transitive verbs) but with non-corresponding structures (Quirk et al., 1985, p. 160), in which either the subject of the English passives translatedas the subject of the Vietnamese actives, or part of it becomes the subject in the translated sentence, or not translated.

(8) Also, the dogs were fed.

$\begin{array}{llllll}\text { Các } & \text { con chó } & \text { cũng } & \text { được }^{4} & \text { ăn } & \text { uống. } \\ \text { (plural } & \operatorname{dog} & \text { also } & \text { have a chance } & \text { eat } & \text { drink) }\end{array}$

(= Dogs had a chance to eat and drink.)

In the above example, the subject of the English passive ('dogs') is also the subject of the Vietnamese active. If the sentence were translated as 'Người ta-cũng-cho-các-con chó-ăn' (They-also-fed-the dogs), the structure would be corresponding with the English passive.

(9) "But if you have got them to-day," said Elizabeth, "my mother's purpose will be answered."

"Nhưng nếu hôm nay cha cần ngựa thì mẹ đạt được mục đích rồi," 
Elizabeth nói.

(but if today dad need horse then mum achieve purpose already)

In the example No.9, a part of the subject in the English passive 'mother' becomes the subject of the Vietnamese activesentence. The translated clause sounds natural in Vietnamese as the subject 'mẹ' ('mum'), an animate noun, goes in line with the subject of the first clause 'cha' ('dad').

(10) "Something must be done," he said.

$\begin{array}{cccccc}\text { Cần phải } & \text { quyết định } & \text { cách } & \text { nào đó, } & \text { anh ta } & \text { nói. } \\ \text { (must } & \text { decide } & \text { way } & \text { somehow } & \mathrm{He} & \text { say) }\end{array}$

In example No.10 above, the Vietnamese active sentence has no subject, but from the context the agent is understood to be a group of people, a member of which is the speaker.

In addition, we have also observed two cases when the complement adverbial phrase in the English passives is the subject of the Vietnamese actives.

(11) He was carted about in another wagon; a truck carried him, with an assortment of boxes and parcels, ...

$\begin{array}{llllllllllll}\begin{array}{l}\text { Một chiéc xe ngụa } \\ \text { chiếc xe tải lại }\end{array} & \text { mang } & \text { nó } & \text { đi } & \text { cùng } & \text { một } & \text { đống } & \text { những } & \text { hòm } & \text { và } & \text { gói, ... } \\ \text { (one wagon } & \text { another carry } & \text { Buck } & \text { to } & \text { one } & \text { place } & \text { certain; } & \text { then } & \text { one } & \\ \text { truck again } & \text { carry } & \text { it } & \text { go } & \text { together } & \text { one } & \text { pile } & \text { plural } & \text { box } & \text { and parcel) }\end{array}$

(= A wagon carried Buck somewhere; then a truck again carried him with a lot of boxes and parcels.)

The above translated Vietnamese sentences sound natural with the two subjects both denoting vehicles, 'a wagon' and 'a truck'. Thus, although the Vietnamese active structure is non-corresponding with the English passive, it corresponds with the second Vietnamese active clause.

English passives translated into Vietnamese actives (intransitive verbs)

In this study, we have found 22 English passive clauses which have been translated into Vietnamese actives (intransitive verbs). 18 out of 22 translated clauses share one similarity: the subjects of the English passives become the subjects of the Vietnamese active clauses, while in the other two clauses the adverbial phrase of the English passives becomes the subjects, and the rest two clauses have an active-passive correspondence with the English passives. Among the 18 clauses, 16 Vietnamese clauses have the subject being rendered from the English subjects, and two clauses are with added nouns.

(12) The chase was resumed.

$\begin{array}{llll}\text { Cuộc } & \text { săn đuổi } & \text { lại } & \text { tiếp diễn. } \\ \text { (noun } & \text { chase } & \text { again } & \text { go on) }\end{array}$

In the example No.12 above, the subject of the English passive sentence has been translated as the subject of the Vietnamese active sentence.

(13) His whole body was gathered compactly together in the tremendous effort, ...

$\begin{array}{llllllll}\text { Sức mạnh } & \text { toàn } & \text { thân } & \text { Bấc } & \text { thu hết lại } & \text { thành } & \text { một } & \text { khối } \\ & \text { rắn chắc } & \text { trong } & \text { một } & \text { nỗ lực } & \text { ghê gớm } & \text { ậy. } & \\ \text { (strength } & \text { whole } & \text { body } & \text { Buck } & \text { gather } & \text { into } & \text { one } & \text { mass } \\ & \text { solid } & \text { in } & \text { one } & \text { effort } & \text { tremendous } & \text { that) } & \end{array}$

In the example No.13, the word 'Sức mạnh', meaning 'strength', has been added to the translation of the English passive sentence, which makes the meaning clearer and sounds totally natural in Vietnamese.

In this strategy for translating English passives, in two Vietnamese clauses the subjects have been rendered from the prepositional phrases in the English passives. It should also be noted here that in these two cases the English sentencesare semi-actives (Quirk et al., 1985, p. 168) with the agent-like phrases 'with the courage of fear', and 'with ice'. Thus, there is no surprise when these phrases become the subjects in the Vietnamese translations.

(14) He was animated now with the courage of fear.
Lúc
này
trong
gã
dấy lên lòng can đảm
của
khiếp sọ. 
(time this in he/him rise courge of fear)

(15) They were coated solidly with ice,...

$\begin{array}{lllllllll}\text { Băng } & \text { đóng } & \text { chặt } & \text { thành } & \text { lớp } & \text { cứng } & \text { quanh } & \text { thân } & \text { chúng, ... } \\ \text { (ice } & \text { coat } & \text { solidly } & \text { into } & \text { layer } & \text { hard } & \text { around } & \text { body } & \text { they/their) }\end{array}$

Interesting enough, only two Vietnamese translated sentences have a corresponding structure with the English passive, i.e. the objects of the English passives become the subjects of the Vietnamese actives. Example No. 16 below is one of the two sentences.

(16) Mr. Bingley had danced with her twice, and she had been distinguished by his sisters.

Bingley mời cô khiêu vũ đến hai lần, chị em anh cư xử khá thân thiện với cô. (Bingley invite she dance up to two time, sisters he/his behave quite friendly with she) (= Bingley invited her to dance twice, his sisters behaved in a quite friendly manner towards her)

In short, in this section, 3.3.2, we have provided an analysis of Vietnamese active clauses (with transitive and intransitive verbs) as the translations of the English passives, totaling 76 clauses. 54 out of 157 English passive clauses in the literary texts have been translated into Vietnamese active clauses (with transitive verbs) $(34.4 \%)$, among which clauses with corresponding structures account for $21.7 \%$, while $12.7 \%$ of clauses are with non-corresponding structures. 22 out of $157(14 \%)$ translated clauses have intransitive verbs, among which eighteen are with the subjects being rendered from the subjects of the English passives, while in the other two clauses the agent-like phrases in English become the subjects, and in two clauses a passive - active corresponding structure with the English passive is observed.

We would argue that the translated Vietnamese actives (both with transitive and intransitive verbs) are semantically equivalent to those English passives as these actives sound natural in Vietnamese.

\subsubsection{English Passives Translated into Clauses with Ergative Verbs}

As can be seen in Table 1 above, there are 12 out of 157 English passives translated into Vietnamese clauses with ergative verbs, accounting for $7.6 \%$ of the total data in this study. In what follows, we will analyse the translation of the English verbs into Vietnamese ergative verbs. In the twelve English passives, ten different verbs are used, 'force'is present in two sentences, and the same is for 'oblige'.

Table 6. Translation of English verbs into Vietnamese ergative verbs

\begin{tabular}{ccc}
\hline No. & English verbs & Vietnamese ergative verbs \\
\hline 1. & Renew: transitive & tiếp tục ('continue') \\
2. & Be born: used only in the passive, without by & sinh ra ('be born', 'give birth to') \\
3. & Wrap: transitive & quấn ('wrap') \\
4. & Coat: transitive (often passive) & phủ kín ('fully cover') \\
5. & Build: transitive & nhóm lên ('make/light a fire') \\
6. & Halt: transitive & dừng lại ('stop/ halt') \\
7. & Resume: transitive, intransitive & tiếp tục ('continue') \\
8. & Force: transitive (often passive) & buộc phải ('force') \\
9. & Oblige: transitive (usually passive) & buộc phải ('force') \\
10. & Open: transitive, intransitive & mở ra ('open') \\
\hline
\end{tabular}

Table 6 above shows three groups of English verbs: first, transitive verbs: 'renew', 'coat', 'built', 'halt', 'force', and 'oblige', with three of which being often used in the passive ('coat', 'force', and 'oblige'); second, ergative verbs: 'resume', and 'open', with the latter being a common ergative verb ${ }^{5}$; and third, a verb used only in the passive 'be born'.

(17) Jane was therefore obliged to go on horseback, and...

$\begin{array}{lllllll}\text { Vì thế } & \text { Jane } & \text { buộc phải } & \text { cưỡi } & \text { ngựa } & \text { mà } & \text { đi... } \\ \text { (Therefore } & \text { Jane } & \text { forced/ be forced } & \text { ride } & \text { horse } & \text { to } & \text { go...) }\end{array}$

(= Therefore, Jane was forced to go on horseback...)

The literal translation of the above sentence is 'Vì thế Jane bị buộc phải cưỡi ngựa mà đi...'. However, as stated 
earlier in this paper, the active sentence sounds more natural to the Vietnamese ears, which is probably the reason for the translator's choice of a translation strategy without the passive marker $b i$.

(18) Here he was born, and here he had lived the four years of his life.
Tại nơi đây Bấc
đã $\sinh \mathbf{r a}^{6}$, và cũng tại nơi đây Bấc đã trải qua bốn năm tuổi đời của nó.
(In place this Buck past tense bear,
bear, and also in place this Buck past tense live four year life of
he)

(= Here Buck was born, and also here he had lived four years of his life)

The explanation for the choice of translation option without a passive marker 'bị'/ 'được' is the same as in the exampleNo. 17.

\subsubsection{English Passives Translated into Clauses with Adjectives or Adjectival Phrases}

As Table 1 shows, the English passives translated into Vietnamese clauses with adjectives or adjectival account for $3.2 \%$ of the data (five sentences).

(19) His face and body were scored by the teeth of many dogs, and ...

$$
\begin{array}{llllllllll}
\text { Mặt mũi } & \text { và } & \text { thân mình } & \text { nó } & \text { đầy } & \text { vết } & \text { răng } & \text { của } & \text { nhiều } & \text { con chó, } \ldots \\
\text { (face nose } & \text { and } & \text { body } & \text { he/his } & \text { full } & \text { mark } & \text { tooth } & \text { of } & \text { many } & \operatorname{dog} \text { ) }
\end{array}
$$

(20) His face was stamped with twenty-five years of incessant struggle with Nature in her wildest moods,...

$\begin{array}{lllllllll}\text { Khuôn mặt } & \text { Biriuc } & \text { còn } & \text { đậm } & \text { dấu ấn } & \text { của } & \text { hai mươi lăm } & \text { năm } & \text { vật lộn } \\ & \text { với } & \text { các } & \text { thế lực } & \text { hung bạo } & \text { của } & \text { thiên nhiên,... } & & \\ \text { (face } & \text { Biriuc } & \text { still } & \text { full } & \text { mark } & \text { of } & \text { twenty five } & \text { year } & \text { struggle } \\ & \text { with } & \text { plural force } & \text { violent } & \text { of } & \text { nature) } & & \end{array}$

In the example No. 19, the English passive verb 'were scored' was translated into Vietnamese as 'đầy' meaning 'full', and in the example No. 20 the verb 'was stamped' - into an adjectival phrase meaning 'full of marks'. It should be noted here that the translated sentences sound natural in Vietnamese.

\subsubsection{English Passives Translated into Clauses with Copular Verbs}

As reported in Table 1, in this study we have found three sentences with copular verbs 'là' as the translations of Englishpassives.

(21) He was mastered by the verb "to eat."

$\begin{array}{lllllll}\begin{array}{l}\text { Thống ngự } \\ \text { (master }\end{array} \text { he/ him } & \text { lúc } & \text { này } & \text { là } & \text { động từ } & \text { "Ăn". } \\ \text { (= Mastering him at this moment is the verb 'to eat') } & \text { this } & \text { be } & \text { Verb } & \text { 'eat') }\end{array}$

As can be seen in example No. 21 above, one of the three sentences, the verb in the English passive is the subject in the Vietnamese translated sentence and the copular verb is added as the predicative. The translated sentence sounds natural in Vietnamese, although the sentence structure is changed compared with that of the English passive. It may be said that this is a semantic translation of the English passive sentence.

Similarly, semantic translations are observed in the rest two translated sentences with the verb 'là' in Vietnamese.

\section{Conclusions and Implications}

\subsection{Conclusion}

This study was set out to answer the two questions. In the following section, we will summarize the research results in answering those questions.

Research question 1: Is the translation equivalence between English passive sentences and their Vietnamese counterparts structural, or semantic?

In order to answer this question, the English passives and their translations in Vietnamese in literary discourse have been collected. The data consist of 150 passive sentences in English, more specifically, 157 independent clauses and their translations in Vietnamese. The original clauses and their translated ones are compared and analysed, after that the translations are classified based on Widdowson's (1979) classification of translation equivalence: structural and semantic. 
The data analysis and discussion have shown that English passives have been translated into Vietnamese passives, actives (transitive verbs and intransitive verbs), copular verbs, ergative verbs, and adjectives or adjectivals.

Firstly, with regards to the translated Vietnamese passive clauses, in this study we would argue for complete structural translation equivalence and incomplete structural equivalence. Complete structural equivalence is applied for those clauses with structural correspondence (S-V-O) between the English passives and the translated passives in Vietnamese, while the incomplete structural equivalent clauses are the three passive clauses, in which the object of the verb in the English original clauses is the subject in the translated passive sentence. The proportion of clauses with complete structural equivalence is $36.94 \%$, and that for the translated passives with incomplete structural equivalence is $1.91 \%$. The total percentage for structural equivalence is $38.85 \%$.

Secondly, regarding semantic equivalence, we would argue it for all the rest translated clauses, namely the Vietnameseactives (both transitive and intransitive verbs) $(48.40 \%)$, and all the translated clauses with copular verbs, ergative verbs, adjectives or adjectivals, $(12.73 \%)$. It should be noted again that the translated clauses sound natural in Vietnamese. The total percentage for the semantic translations of literary texts is $61.13 \%$.

It can be concluded that in literary discourse the translation equivalence between English passive sentences and their Vietnamese counterparts is both structural and semantic, and the number of semantically equivalent clauses is just 1.5 times as many as that of structurally equivalent ones.

Research question No. 2: What are some possible factors that may influence the choice of certain translation strategies?

In this study it is shown that translators employ many strategies: activization, passivization, ergativization, adjectivization, and copularization. It is also shown that certain translation strategies are more preferred than others. As can be seen in Table 1, activization is the most preferable strategy, with $48.40 \%$ of the English passives being translated into the Vietnamese active clauses. Second, comes the passivization with $38.85 \%$ of the English passives being rendered into the Vietnamese passives; and third is ergativization (7.64\%).

The claims (Tran, 1998, p. 165; and others) that Vietnamese prefers active voice seem correct. The evidence can be seen in the several examples. Firstly, the structure 'it' with the passive voice, if being literally translated into Vietnamese, does not sound natural, and thus, has been translated into the Vietnamese active one with the hidden agent being the subject. These types of sentences usually begin with the words like 'mọi người' ('everyone'), 'người ta' ('other people'), etc. (see example No. 7). Secondly, activization is also due to the structure of sentences with two or more clauses. If the first English clause is the active, followed by a passive one, or vice versa, then there is a possibility that the passive clause will be rendered into the active (see example No. 9, and example No. 11). Also, in these two examples, the subjects in the translated Vietnamese active clauses are in line with one another, both are family members or vehicles, which makes the sentences sound natural in Vietnamese. Thirdly, agent-like phrases (plus preposition "with") in the English semi-actives become the subjects in the Vietnamese actives (intransitive verbs), which suits the preference for active constructions in Vietnamese. In addition, in twelve Vietnamese sentences with ergative verbs, the passive marker 'bi' / 'được' is not employed, although in theory it can be used, perhaps, for the same reason.

It may be concluded that activization of the English passives is influenced by the preference for active constructions, which is a linguistic characteristic of Vietnamese, (Tran, 1998, p. 165; Than, 1977, p. 211; Baker, 1992, p. 102).

\subsection{Implications}

The research findings in this study indicate that there are different strategies for translating the English passives into Vietnamese in literary discourse, namely activization, passivization, ergativization, adjectivization, and copularization, among which activization is the most preferable translation strategy. In addition, it is suggested that the structural equivalence in Widdowson's trichotomy may have been widened to include complete and incomplete structural equivalence. Also, further research can be carried out on the Vietnamese preference of active sentences with a larger parallel corpus between English and Vietnamese.

\subsection{Limitations}

It should be noted here that the unit for literary translation is not always at sentence level (Bassnett, 2002, p.120). However, due to the scope of this study, we could only employ the structural and semantic equivalence in Widdowson's trichotomy, although we understand that pragmatic equivalence may give a chance to have a closer look at the context of the translated sentences in Vietnamese. In addition, the naturalness of the translated sentences would be more convincing, if native Vietnamese readers' responses to them were collected. These are 
the limitations of this study.

\section{Acknowledgements}

I am grateful to Hong Con Nguyen for his comments and suggestions while this research was being carried out. All errors are mine. This research is funded by International School, Vietnam National University, Hanoi, (VNU-IS), under the Project No. CS.NNC/2021-05.

\section{References}

Abbasi, A., \& Arjenan, F. M. (2014). Translation of English Passive and Unaccusative Verbs into Farsi: A Comparative Study of Three Translations of 'Animal Farm' by Three Iranian Translators. Procedia - Social and Behavioral Sciences, (98), 9-15. https://doi.org/10.1016/j.sbspro.2014.03.382

Alves, M. (1998). Passive voice or affective verbs in Vietnamese? In D. Yoshimi, \& M. Plumlee (Eds.), The Life of Language, the Language of Life (pp. 113-117). University of Hawaii at Manoa: National Foreign Language Resource Center.

Baker, M. (1992). In Other Words: A Course Book on Translation. NY, USA: Routledge.

Bassnett, S. (2002). Translation Studies (3rd ed.) London \& New York: Routledge

Bussmann, H. (Ed.) (1996). Routledge Dictionary of Language and Linguistics. New York: Routledge.

Cao, X. H. (2001). Hai phép tính cộng và trừ trong ngôn ngữ học [Two operations: addition and subtraction inlinguistics] Tạp chí Ngôn ngũu [Language Review] 10(141), 1-12. Hanoi: Institute of Linguistics.

Catford. (1965). A Linguistic Theory of Translation. Oxford: OUP.

Clark, M. (1974). Passive and Ergative in Vietnamese. In D. L. Nguyen (Ed.), South-east Asian Linguistics Studies (1) (pp. 75-88). The Australian National University: Pacific Linguistics.

Diep, Q. B. (2006). Ngũ pháp tiếng Việt [Vietnamese Grammar]. Tái bản lần 2 [2 $2^{\text {nd }}$ ed.]. Tập 2 [Vol.2]. Hà Nội: Nhà xuất bản Giáo dục [Hanoi: Education Publishing House].

Dinh, V. D. (1986). Ngũ pháp tiếng Việt - Tù loại [Vietnamese Grammar - Parts of Speech]. Hà Nội: ĐHQG [Hanoi:Vietnam National University].

Farghal, M., \& Al-shorafat, M. (1996). The Translation of English Passives into Arabic: An Empirical Perspective. Target, 8(1), 97-118. Amsterdam: John Benjamins. Retrieved from https://benjamins.com/online/target/articles/target.8.1.06far

Hoang, C. B. (2015). Các phương thức dịch câu bị động tiếng Anh sang tiếng Việt [Strategies for translating English passive sentences into Vietnamese]. Tạp chí Ngôn ngũ \& Đời sống [Journal Language \& Life] 2 (232), 48-53. Hanoi: Institute of Linguistics.

Hoang, P. (Ed.) (2003). Tù điển tiếng Việt [Vietnamese Dictionary] Institute of Linguistics. Hanoi-Da Nang: Da Nang Publishing

Keenan, E. L., \& Dryer M. S. (2007). Passive in the world's languages. In Shopen T. (Ed.), Clause structure, language typology and syntactic description (2nd ed., Vol. 1, pp. 325-361). Cambridge University Press.

Kenny, D. (2009). Equivalence. In M. Baker, \& G. Saldanha, (Eds.), Routledge Encyclopedia of Translation Studies (2nd ed., pp. 96-99). London \& New York: Routledge.

Koller, W. (1989). Equivalence in translation studies. In A. Chesterman (Ed.), Readings in Translation Theory (pp. 99-104). Helsinki: Oy Finn Lectura Ab.

Luu, T. T (2010). Strategies for Translating the Passive Structure in Scientific Discourse. Asian Social Science, 6(7) 97-107. Canadian Center of Science and Education. https://doi.org/10.5539/ass.v6n7p97

Nahar Al-Ali, M., \& Alliheibi, F. M. (2015). Struggling to Retain the Functions of Passive When Translating English Thesis Abstracts. Pragmatics, 25(2), 129-148. International Pragmatics Association. https://doi.org/10.1075/prag.25.2.01ala

Nguyen, D. H. (1996). Vietnamese verbs. The Mon-Khmer Studies Journal, 25, 141-159.

Nguyen, H. C. (2009). Vietnamese Passive Sentences from a Typological Perspective. Journal of the Southeast AsianLinguistics Society, 2, 107-120.

Nguyen, H. C., \& Bui, T. D. (2004). Dạng bị động và vấn đề câu bị động trong tiếng Việt, phần 1 [Passive voice and issues of passive sentences in Vietnamese, Part 1]. Tạp chí Ngôn ngũu [Language Review] 7(182), 1-12. 
Hanoi: Institute of Linguistics.

Nguyen, H. C., \& Bui, T. D. (2004). Dạng bị động và vấn đề câu bị động trong tiếng Việt, phần 2 [Passive voice and issues of passive sentences in Vietnamese, Part 2]. Tạp chí Ngôn ngũu [Language Review], 8 (183), 8-18. Hanoi: Institute of Linguistics.

Nguyen, K. T. (1977). Động tù trong tiếng Việt [Verbs in Vietnamese language]. Hà Nội: NXB Khoa học Xã hội [Hanoi: Social Sciences Publishing House].

Nguyen, M. T. (1986). Vai trò của các từ 'bị', 'được' trong câu bị động tiếng Việt [The roles of 'bị', 'được' in Vietnamese passive sentences]. Nhũng vấn đề các ngôn ngũu phwơng Đông [Linguistic issues on Oriental languages] (pp. 204-207). Viện ngôn ngữ học [Institute of Linguistics].

Nguyen, T. A. (2000). Tiếng Việt có thái độ bị động không? [Is there passive voice in Vietnamese?] Tạp chí Ngôn ngũ [Language Review], 5, 36-47. Hanoi: Institute of Linguistics.

Nida, E. (1964/2000). Principles of Correspondence, in Venuti, L. (Ed.), The Translation Studies Reader (pp. 126-140). London: Routledge.

Nida, E., \& Taber, C. (1969/reprinted 1982). The Theory and Practice of Translation. Leiden, the Netherlands: E.J. Brill.

Pham, T. T. (2020). Cách phân loại tương đương dịch thuật ở cấp độ câu và khả năng áp dụng vào nghiên cứu dịch thuật Anh-Việt [Translation equivalence classification at sentence level and applicability to English-Vietnamese translation studies]. Kỷ yếu Hội thảo Quốc tế 'Dịch thuật thời đại 4.0: Đào tạo, nghiên cúu và thưc tiến - 2020' [Proceedings of International conference 'Translation 4.0: Training, Research \& Practive - 2020] (pp. 449-458). Hà Nội: Nhà xuất bản ĐHQGHN [Hanoi: VNU Publishing House].

Pham, T. T. (2020). Cấu trúc bị động tiếng Anh và cấu trúc dịch tương đương tiếng Việt trong ngôn bản văn học [English passive constructions and equivalent constructions in Vietnamese in literary discourse]. Ky yếu Hộ $i$ thảo Khoa học Quốc gia 2020: 'Nghiên cứu và giảng dạy ngoại ngũu, ngôn ngũu \& quốctế học tại Việt Nam' [Abstract booklet of National conference 2020: 'Researching and teaching foreign languages, linguistics and international studies in Vietnam'] (p. 107). Hà Nội: Đại học Ngoại ngữ - ĐHQGHN [Hanoi: ULIS-VNU].

Quirk, R., Greenbaum, S., Leech, G., \& Svartvik, J. (1985). A Comprehensive Grammar of the English Language. NewYork: Longman.

Simpson, A., \& Ho, H. T. (2008). The Comparative Syntax of Passive Structures in Chinese and Vietnamese. In M. K. M. Chan, \& H. Kang (Eds.), Proceedings of the $20^{\text {th }}$ North American Conference on Chinese Linguistics (NACCL-20) 2 (pp. 825-841). Columbus, Ohio: The Ohio State University.

Snell-Hornby, M. (1988/1995). Translation Studies: An Integrated Approach. Amsterdam: John Benjamins Publishing.

Thompson, L. C. (1987). A Vietnamese Grammar. USA: University of Hawaii Press.

Tran, N. T. (1998). Co sở văn hóa Việt Nam [Basis of Vietnamese Culture]. Tp HCM: NXB Giáo dục [Hochiminhcity: Education Publishing House]

Widdowson, H. G. (1979). The deep structure of discourse and the use of translation. In C. J. Brumfit, \& K. Johnson (Eds.), The Communicative Approach to Language Teaching (pp. 61-71). Oxford University Press.

\section{Sources for Data}

Austen, J. (1813). Pride and Prejudice. Retrieved from https://www.gutenberg.org/files/1342/1342-h/1342h.htm

Doan, T. H. (2012). Một trạm nghỉ. In Truyện ngắn Jack London, 516-538. [Jack London’s Short Stories]Hà Nội: NXB Văn học [Hanoi: Literature Publishing House].

Duong, T. (2012). Tình yêu cuộc sống. In Truyện ngắn Jack London, 151-176 [Jack London's Short Stories]. Hà Nội: NXB Văn học [Hanoi: Literature Publishing House].

Lam, Q. A., \& Thien N. (2016). Kiêu hãnh và định kiến. Hà Nội: Nhà xuất bản Hội nhà văn [Hanoi: Writers' Association Publishing House]

London, J. (1900). The Son of the Wolf . Retrieved from http://www.gutenberg.org/ebooks/2377

London, J. (1900). The White Silence. In The Son of the Wolf. Retrieved from 
http://www.gutenberg.org/ebooks/2377

London, J. (1903). A Day's Lodging. In Love of Life and Other Stories. Retrieved from A Day's Lodging (americanliterature.com)

London, J. (1903). Love of Life. In Love of Life and Other Stories. Retrieved from Love of Life (gutenberg.org)

London, J. (1903). The Call of the Wild. Retrieved from http://www.gutenberg.org/ebooks/215

Nguyen, C. A., \& Vu, T. P. (2012). Tiếng gọi nơi hoang dã. In Truyện ngắn Jack London, 19-150 [Jack London's Short Stories]. Hà Nội: NXB Văn học [Hanoi: Literature Publishing House].

Nguyen, H. (2012). Con trai của chó Sói. In Truyện ngắn Jack London, 383-405 [Jack London’s Short Stories]. Hà Nội: NXB Văn học [Hanoi: Literature Publishing House].

Thai, B. T. (2012). Sự im lặng màu trắng. In Truyện ngắn Jack London, 5-18 [Jack London's Short Stories]. Hà Nội: NXB Văn học [Hanoi: Literature Publishing House].

\section{Notes}

1 Note 1: These examples are taken from Quirk et al (1985, pp. 167-169).

2 Note 2: The back translation into English is provided in the brackets under each example.

${ }^{3}$ Note 3: Source: https://dictionary.cambridge.org/grammar/british-grammar/it

4 Note 4: 'được' here is not a passive marker, but it has the meaning of 'to receive or undergo something pleasant' (D.H. Nguyen, 1996, p. 143; K.T. Nguyen, 1977, p. 201)

5 Note 5: Source: https://learnenglish.britishcouncil.org/english-grammar-reference/ergative-verbs

6 Note 6: 'sinh ra': Mẹ sinh ra tôi (Mother gave birth to me); Tôi được sinh ra / Tôi sinh ra năm 2000 (I was born in 2000).

\section{Copyrights}

Copyright for this article is retained by the author(s), with first publication rights granted to the journal.

This is an open-access article distributed under the terms and conditions of the Creative Commons Attribution license (http://creativecommons.org/licenses/by/4.0/). 